UNDERGROUND MINING ENGINEERING 31 (2017) 67-76 $\quad$ UDK 62

\title{
INJURIES FREQUENCY OF EMPLOYEES IN UNDERGROUND COAL MINES IN SERBIA
}

\author{
Vladimir Todorović ${ }_{-}^{1}$, Dejan Petrović 2 , Jelena Trivan ${ }^{3}$
}

Received: November 5, 2017

Accepted: December 12, 2017

\begin{abstract}
The work in underground coal mines is one of the most difficult activities. General characteristic of working condition these mines are contained in the fact that all coal mines are in the low mechanized level which produce heavy manual work, low productivity and high financial costs. High risk level of injuries and occupational diseases are special problems in these working conditions. The workers disability is also huge problem. All of these produce a production and financial loses. Based on a comprehensive overview of the natural and geological conditions in the coal seams, technical and technological solutions for exploitation in active mines and injuries analysis in this paper, the frequency of injuries with the basic influencing parameters for the period 2014-2016 is given. In the analysis of this topic, the methods of analysis and synthesis were mainly used, and real parameters were obtained and from them high quality conclusions were coming out.
\end{abstract}

Keywords: coal mine; coal; injuries; safety and health at work;

\section{INTRODUCTION}

In underground coal mines in Serbia, which are organized as a state-owned company PE PEU - Resavica, exploitation of quality anthracite, bituminous coal and lignite is carried out. Currently, eight coal mines are active with 11 underground productive units which are located in western, central and eastern parts of the country. The main characteristic of underground coal mining is the mutual coherence and cohesion in time and space of the main working processes starting from exploration, opening, development, excavation hauling and hoisting to the following processes such as ventilation, dewatering etc. Human work is included in all of these phases and high risk level of injury is also attendant.

The general characteristics of underground coal mines, including working conditions and high risk level of injuries during the working processes, are (Ćurčić et al., 1981):

\footnotetext{
1 JP PEU - Resavica

${ }^{2}$ University of Belgrade-Technical Faculty in Bor

${ }^{3}$ University of Banja Luka - Faculty of Mining Prijedor

Emails: vladimirtodorovic@live.com.au; dpetrovic@tfbor.bg.ac.rs; jelena.trivan@rf.unibl.org
} 
- Working operations of coal excavation process are performed in the underground mining drifts with limited work space;

- The mining drifts and crosscuts are exposed to constant influence of mine pressure and the employees are also exposed to potentially dangerous of working space collapses, the fall of coal and overburden from the sides and roof;

- Geological conditions of exploitation and applied technical solutions cause separation of congestion, toxic and explosive gases and dangerous and harmful concentrations of coal dust.

- Potential possibilities for irruption of large amounts of water and sludge into underground mining facilities that can cause sinking of mines and employee injuries.

- The possibilities to provide and changing clean air are difficult in mining drifts;

- The employees in the coal mines are exposed to the influence of higher temperature differences in different parts of mine and other unfavorable ergonomic conditions;

- There are potential possibilities for the occurrence of endogenous and exogenous fires in the coal mines, which can lead to mining disasters, group or individual injuries;

- Limited lighting possibilities of mining drifts may be potential causes of injuries;

- Exposure of workers to the harmful effects of noise and vibration, which is the cause of occupational diseases.

These characteristics make work under conditions of underground exploitation particularly harmful and dangerous to the life and health of workers, resulting in personal and collective cases of injuries and occupational diseases. The most important research on the topic of injuries in coal mines in Serbia was done by Stojadinović et al. (2012). Injuries for a 10 years period in PE PEU were analyzed in this paper.

This work will result from the fact that in the meantime, the mines have introduced new legal acts and measures that have been implemented based on them, among which the most important Risk Assessment Workplace Act. This led to a significant reduction in the number of injuries on mines.

\section{INJURIES OCCURENCE IN COAL MINES}

When solving the problem of protection and safety of work in underground coal mines it is necessary to analyze in detail the natural and technical-technological conditions and to evaluate the possible negative effects on the functioning of the work process and the emergence of potential hazards to the safety and health of employees. 
According to the current law dealing with occupational safety and health at work, accidents at work are any injury caused by immediate and short-term physical, chemical or mechanical action, as well as injuries caused by sudden changes in the physiological state of the organism, when this injury is causally related to the performance of work on specific workplace. Related to the concept of an accident at work is the concept of an mishap at work, and he represents an unplanned, unforeseen, unwanted and uncontrollable events, which may result in injury or property damage, or both.

A dangerous event is the unsafe contact of a man with a material factor, or the harmful effect of a material factor on man, which occurred in connection with the performance of the work during which the employee was injured. Knowing the type of dangerous event determines the immediate causes or circumstances related to the site where the injury occur, which directly acted on its occurrence.

In the case of mining accidents, there are usually several causes that have occurred in some order, so that at least one immediate and a number of indirect causes are affected by the injury.

\section{FREQUENCY ANALYSIS OF INJURY AND CHARACTERISTICS OF INJURIES}

In order to show the frequency of injuries of employees in underground coal mines in Serbia, numerous documentary sources have been used: reports on injuries in mines, annual reports on the state of safety and health at work, expert analysis of serious and fatal injuries, reports on the work of the mines (monthly and annual), both in underground mining units and mines, as well as in total for all mines in the company JP PEU - Resavica. The data (JP PEU, 2016; Ivković, 2010, 2012) were selectively collected, and then systematized by key factors and then analyzed in detail and calculated the basic parameters of the injuries. In addition to the presentation of the key parameters of the frequency of injuries, the causes and sources of injury were specifically addressed, with a correlation with the locations of the injuries.

The cause of the injury is the irregular procedure, that is, the action of workers in the conditions of existence of a particular danger, while the source of the injury is defined as an objective or subjective factor (object, matter, person, place, which occurs at the place of the injury or in its adjacency and contains defects, etc.) which resulted in an injury to the employee. In practice, sources or cause of the injuries are wrong identified or incorrectly stated, and the quality of the injury analysis depends on the experience of the person who performs the analysis and its knowledge of the technological process and theoretical knowledge of the occurrence of the injury. 
The paper also presents the working day losses due to sickness, both caused by injuries and illnesses, and a comparison with the productive working days.

Table 1 Injuries by mines that are the subject of analysis

\begin{tabular}{|c|c|c|c|c|c|c|c|c|c|c|c|}
\hline \multirow[b]{2}{*}{ Year } & \multicolumn{9}{|c|}{ MINE } & \multirow[b]{2}{*}{ Administration } & \multirow[b]{2}{*}{ Total } \\
\hline & 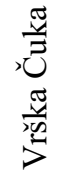 & 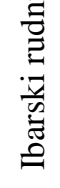 & 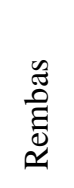 & $\begin{array}{l}\text { Od } \\
\text { b }\end{array}$ & 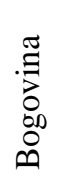 & 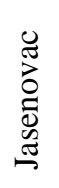 & 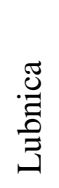 & 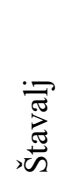 & 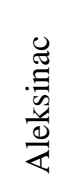 & & \\
\hline 2014 & 7 & 8 & 139 & 93 & 17 & 24 & 17 & 51 & 78 & 1 & 435 \\
\hline 2015 & 8 & 10 & 171 & 85 & 16 & 31 & 28 & 66 & 81 & 0 & 496 \\
\hline 2016 & 6 & 13 & 119 & 68 & 21 & 18 & 43 & 59 & 57 & 1 & 405 \\
\hline$\Sigma$ & 21 & 31 & 375 & 246 & 54 & 73 & 88 & 176 & 216 & 2 & 1336 \\
\hline
\end{tabular}

The largest number of injuries, in the observed period (table 1), occurred in RMU "Rembas", considering that in this mine, mining works are performed in 3 underground mining units, and this mine has the largest number of employees. After Rembas, in Aleksinac mines there is also a high number of injuries. This is the result of more intensive work and the application of a drilling and blasting system of making drifts, because their workers work exclusively in the drifts making.

Table 2 Summary view of injuries by category

\begin{tabular}{ccccc}
\hline \multirow{2}{*}{ Year } & \multicolumn{4}{c}{ Categories of injuries } \\
\cline { 2 - 5 } & Light injuries & Heavy injuries & Fatal injuries & Total \\
\hline 2014. & 394 & 40 & 1 & 435 \\
2015. & 450 & 46 & 0 & 496 \\
2016. & 350 & 55 & 0 & 405 \\
$\Sigma$ & 1194 & 141 & 1 & 1336 \\
\hline
\end{tabular}

Out of the total of 1,336 injuries that occurred in the observed period, 1194 injuries were categorized as light, with a percentage share of $89.3 \%$ in the total number of injuries. 
Ninety years of mining and metallurgy...

Table 3 Injuries rates according to qualification structure

\begin{tabular}{cccccccc}
\hline \multirow{2}{*}{ Year } & \multicolumn{7}{c}{ Injuries qualification structure } \\
\cline { 2 - 8 } & NK & PK & KV & VKV & SSS & VSS & Total \\
\hline 2014. & 151 & 74 & 186 & 12 & 11 & 1 & 435 \\
2015. & 168 & 72 & 231 & 5 & 19 & 1 & 496 \\
2016. & 143 & 69 & 177 & 4 & 8 & 4 & 405 \\
$\Sigma$ & 462 & 215 & 594 & 21 & 38 & 6 & 1336 \\
\hline
\end{tabular}

According to the qualification, the highest number of injuries is recorded in qualificate workers group, with a share in the total number of injuries of $44.4 \%$, table 3 . Such a trend of injuries is expected given that coal excavation is done by qualified miners, and they are exposed to the highest risk of injury. Unskilled workers are mainly engaged in the delivery of the necessary material, which is usually performed manually in the excavation area and preparation crosscuts.

Table 4 Injuries rates according to workers age structure

\begin{tabular}{ccccccccc}
\hline \multirow{2}{*}{ Year } & \multicolumn{7}{c}{ Age } \\
\cline { 2 - 9 } & $20-25$ & $25-30$ & $30-35$ & $35-40$ & $40-45$ & $45-50$ & $\begin{array}{c}50 \text { and } \\
\text { more }\end{array}$ & Total \\
\hline 2014. & 41 & 54 & 72 & 77 & 85 & 57 & 49 & 435 \\
2015. & 36 & 68 & 83 & 79 & 105 & 63 & 62 & 496 \\
2016. & 26 & 55 & 72 & 70 & 70 & 64 & 48 & 405 \\
$\Sigma$ & 103 & 177 & 227 & 226 & 260 & 184 & 159 & 1336 \\
\hline
\end{tabular}

Interesting is the analysis of the number of injuries according to the age structure where the highest number of injuries was recorded to the workers who have over ten years of work experience, Table 4 . This generation of workers relaxed and without fear accessing to the working activities, therefore they are less cautious and therefore exposed to the highest risk of injury. Workers with a working experience of up to five years approaching with their work tasks with great care, so the number of injuries in this category is lower. Workers who have several years to retire are also behaving the same way.

Table 5 Injuries by days of the week

\begin{tabular}{ccccccccc}
\hline \multirow{2}{*}{ Year } & \multicolumn{7}{c}{ Day of the week } \\
\cline { 2 - 9 } & Monday & Tuesday & Wednesday & Thursday & Friday & Saturday & Sunday & Total \\
\hline 2014. & 71 & 68 & 75 & 58 & 56 & 46 & 61 & 435 \\
2015. & 80 & 80 & 63 & 88 & 70 & 51 & 64 & 496 \\
2016. & 78 & 59 & 54 & 68 & 69 & 39 & 38 & 405 \\
$\Sigma$ & 229 & 207 & 192 & 214 & 195 & 136 & 163 & 1336 \\
\hline
\end{tabular}


From the Table 5 can be seen that the day of the week does not have any effect on the occurrence of injuries.

Table 6 Injuries by working shifts

\begin{tabular}{ccccc}
\hline \multirow{2}{*}{ Year } & \multicolumn{4}{c}{ Working shift } \\
\cline { 2 - 5 } & I & II & III & Total \\
\hline 2014. & 201 & 132 & 102 & 435 \\
2015. & 222 & 154 & 120 & 496 \\
2016. & 171 & 153 & 81 & 405 \\
$\Sigma$ & 594 & 439 & 303 & 1336 \\
\hline
\end{tabular}

The number of injuries in the 1st shift is the largest (44.4\%), considering that the most of service jobs are carried out in the 1st shift, and that in the first shift works the most workers.

Table 7 Injuries according to hours of work in shifts

\begin{tabular}{cccccccccc}
\hline \multirow{2}{*}{ Year } & \multicolumn{8}{c}{ Hours of work in shifts } \\
\cline { 2 - 10 } & 1 & 2 & 3 & 4 & 5 & 6 & 7 & 8 & Total \\
\hline 2014. & 20 & 52 & 74 & 68 & 88 & 78 & 41 & 14 & 435 \\
2015. & 37 & 61 & 86 & 77 & 93 & 90 & 35 & 17 & 496 \\
2016. & 26 & 46 & 74 & 87 & 64 & 59 & 33 & 16 & 405 \\
$\Sigma$ & 83 & 159 & 234 & 232 & 245 & 227 & 109 & 47 & 1336 \\
\hline
\end{tabular}

The first and last two hours in shift are for hours with the lowest number of injuries. In these parts of the shift there preparatory and final operations are performed at the work sites. Therefore, the number of injuries is the smallest, while in the production part of the shift from the third to the sixth working hour the greatest number of injuries is occurred.

Table 8 Injuries according to the injured parts of the body

\begin{tabular}{cccccccccc}
\hline \multirow{2}{*}{ Year } & \multicolumn{10}{c}{ Injured part of the body } \\
\cline { 2 - 10 } & Head & Arm & Leg & $\begin{array}{c}\text { Internal } \\
\text { organs }\end{array}$ & Eye & $\begin{array}{c}\text { Spine, } \\
\text { back }\end{array}$ & Face & Other & Total \\
\hline 2014. & 24 & 167 & 154 & 4 & 16 & 28 & 9 & 33 & 435 \\
2015. & 25 & 187 & 182 & 3 & 14 & 31 & 13 & 41 & 496 \\
2016. & 29 & 155 & 140 & 2 & 6 & 31 & 11 & 31 & 405 \\
$\Sigma$ & 78 & 509 & 476 & 9 & 36 & 90 & 33 & 105 & 1336 \\
\hline
\end{tabular}

It is extremely high number of injuries of extremities (hands, feet) in percentage $73 \%$ in the total number of injuries. 
Table 9 Injuries by source of injury

\begin{tabular}{|c|c|c|c|c|c|}
\hline \multirow{2}{*}{ No. } & \multirow{2}{*}{ Source } & \multicolumn{3}{|c|}{ Year } & \multirow{2}{*}{$\Sigma$} \\
\hline & & 2014. & 2015. & 2016. & \\
\hline 1. & Slippy hauls floor & 83 & 61 & 56 & 200 \\
\hline 2. & Elements of the timber & 45 & 118 & 51 & 214 \\
\hline 3. & Piece of coal & 105 & 90 & 87 & 282 \\
\hline 4. & Piece of overburden & 41 & 71 & 66 & 178 \\
\hline 5. & Manual tools & 13 & 12 & 13 & 38 \\
\hline 6. & Parts of the chain conveyor & 30 & 16 & 8 & 54 \\
\hline 7. & Chain & 2 & 1 & 0 & 3 \\
\hline 8. & Nail & 4 & 6 & 12 & 22 \\
\hline 9. & Rope driven monorail & 30 & 19 & 7 & 56 \\
\hline 10. & Ele. motors and equipment & 11 & 21 & 46 & 78 \\
\hline 11. & Drilling tools & 1 & 0 & 0 & 1 \\
\hline 12. & Bunker & 1 & 3 & 0 & 4 \\
\hline 13. & Lifting of ballast & 2 & 1 & 2 & 5 \\
\hline 14. & Lime milk & 1 & 1 & 0 & 2 \\
\hline 15. & Steel support segment & 53 & 28 & 25 & 106 \\
\hline 16. & Plank & 3 & 3 & 0 & 6 \\
\hline 17. & Wire & 2 & 0 & 0 & 2 \\
\hline 18. & Steel door & 1 & 0 & 0 & 1 \\
\hline 19. & Belt conveyor & 1 & 32 & 8 & 41 \\
\hline 20. & Ventilation door & 1 & 0 & 0 & 1 \\
\hline 21. & Chain crane & 1 & 4 & 7 & 12 \\
\hline 22. & Lathe & 1 & 0 & 0 & 1 \\
\hline 23. & Fall from height & 3 & 4 & 7 & 14 \\
\hline 24. & Motor vehicle & 0 & 2 & 3 & 5 \\
\hline 25. & Coal dust & 0 & 1 & 0 & 1 \\
\hline 26. & Boiler, pressure vessels & 0 & 1 & 1 & 2 \\
\hline 27. & Sports hall & 0 & 1 & 0 & 1 \\
\hline 28. & Radiator & 0 & 0 & 1 & 1 \\
\hline 29. & Pump & 0 & 0 & 1 & 1 \\
\hline 30. & Timber segment & 0 & 0 & 2 & 2 \\
\hline 31. & Mining wagon & 0 & 0 & 1 & 1 \\
\hline 32. & Steel hook & 0 & 0 & 1 & 1 \\
\hline 33. & Total: & 435 & 496 & 405 & 1336 \\
\hline
\end{tabular}

According to the source of the injuries, the largest number of injuries occurred after fall pieces coal or overlaying rocks. Also, injuries from heavy objects carried through the mine are also dominant (arched support segments, segments of chain conveyor) as well as parts of rope driven monorail to which the cargo is delivered to the mine, table 9 . 
Table 10 Injuries by causer of injury

\begin{tabular}{|c|c|c|c|c|c|}
\hline \multirow{2}{*}{ No. } & \multirow{2}{*}{ Causer of injury } & \multicolumn{3}{|c|}{ Year } & \multirow{2}{*}{$\Sigma$} \\
\hline & & 2014. & 2015. & 2016. & \\
\hline 1. & Carelessness at work & 373 & 409 & 297 & 1079 \\
\hline 2. & Carelessness during the walk thru the mine & 33 & 31 & 39 & 103 \\
\hline 3. & Sudden drop of coal, waste & 14 & 17 & 21 & 52 \\
\hline 4. & Suddenly craking the keys & 1 & 0 & 0 & 1 \\
\hline 5. & Ignoring Guidelines for the work & 5 & 14 & 27 & 46 \\
\hline 6. & Breaking of screw & 1 & 1 & 0 & 2 \\
\hline 7. & Unused protection equipment & 2 & 2 & 3 & 7 \\
\hline 8. & Device breakdown & 2 & 0 & 0 & 2 \\
\hline 9. & Unsafe work site & 4 & 14 & 14 & 32 \\
\hline 10. & Inattention another worker & 0 & 3 & 2 & 5 \\
\hline 11. & Slippery tread & 0 & 2 & 0 & 2 \\
\hline 12. & Suddenly breaking the hose & 0 & 1 & 0 & 1 \\
\hline 13. & Uncontroled delivery system & 0 & 1 & 0 & 1 \\
\hline 14. & $\begin{array}{l}\text { Sudden activation of manual drilling } \\
\text { equipment }\end{array}$ & 0 & 1 & 0 & 1 \\
\hline 15. & Sadenly breakig of the delivery conteiner & 0 & 0 & 1 & 1 \\
\hline 16. & Sadenly breakig of overlapping clamp joint & 0 & 0 & 1 & 1 \\
\hline 17. & Total: & 435 & 496 & 405 & 1336 \\
\hline
\end{tabular}

Table 11 Number of day lost arising from injuries and occupational illness per year

\begin{tabular}{|c|c|c|c|c|c|c|c|c|c|}
\hline \multirow[b]{2}{*}{ Year } & \multicolumn{3}{|c|}{ Days lost due to injuries } & \multicolumn{3}{|c|}{$\begin{array}{l}\text { Days lost due to the } \\
\text { occupational illness }\end{array}$} & \multicolumn{3}{|c|}{ Total days lost } \\
\hline & $\begin{array}{c}\text { Up to } \\
30 \\
\text { days }\end{array}$ & $\begin{array}{c}\text { Over } \\
30 \\
\text { days }\end{array}$ & Total & $\begin{array}{l}\text { Up to } \\
30 \text { days }\end{array}$ & $\begin{array}{c}\text { Over } \\
30 \\
\text { days }\end{array}$ & Total & $\begin{array}{l}\text { Up to } \\
30 \text { days }\end{array}$ & $\begin{array}{c}\text { Over } \\
30 \\
\text { days }\end{array}$ & Total \\
\hline 2014. & 12530 & 4245 & 16775 & 41068 & 9660 & 50728 & 53598 & 13905 & 67503 \\
\hline 2015. & 13892 & 6297 & 20189 & 45510 & 10758 & 56268 & 56603 & 17055 & 76457 \\
\hline 2016. & 13180 & 7241 & 20421 & 51532 & 11803 & 63335 & 60887 & 19044 & 83756 \\
\hline$\Sigma$ & 39602 & 17783 & 57385 & 138110 & 32221 & 170331 & 171088 & 50004 & 227716 \\
\hline
\end{tabular}

Tables 11 show the days lost due to injuries and illness. In state-owned enterprises, illnesses and injuries are often used for longer absence from work than necessary, so the data in these tables are based on existing data, but do not represent a realistic picture of absence from the work as a result of occupational illness or injury. 
Table 12 Days lost due to injuries vs. works shift which were done

\begin{tabular}{cccccccccc}
\hline \multirow{2}{*}{ Year } & \multicolumn{2}{c}{ Days lost due to injuries or illness } & \multicolumn{2}{c}{ Works shift which were done } & \multicolumn{2}{c}{$\%$} \\
\cline { 2 - 10 } & underground & outside & total & underground & outside & total & $2 / 5$ & $3 / 6$ & $4 / 7$ \\
\hline 1 & 2 & 3 & 4 & 5 & 6 & 7 & 8 & 9 & 10 \\
2014. & 52327 & 15176 & 67503 & 475735 & 282771 & 758506 & 11 & 5,4 & 8,9 \\
2015. & 60458 & 15999 & 76457 & 483537 & 279175 & 762712 & 12,5 & 5,7 & 10 \\
2016. & 66873 & 16883 & 83756 & 496670 & 277420 & 772090 & 13,5 & 6,1 & 10,8 \\
$\Sigma$ & 179658 & 48058 & 227716 & 1455942 & 839366 & 2293308 & 12,3 & 5,7 & 9,9 \\
\hline
\end{tabular}

Table 13 Indicator of injuries

\begin{tabular}{cccccc}
\hline \multirow{2}{*}{ Year } & \multirow{2}{*}{$\begin{array}{c}\text { Number of } \\
\text { injuries }\end{array}$} & Production (t) & $\begin{array}{c}\text { Works shift } \\
\text { which were }\end{array}$ & \multicolumn{2}{c}{ Number of injuries } \\
\cline { 5 - 6 } & & & done & per1000 t & $\begin{array}{c}\text { per 1000 } \\
\text { shiftss }\end{array}$ \\
\hline 2014. & 435 & 565229 & 758506 & 0,76 & 0,57 \\
2015. & 496 & 560651 & 762712 & 0,88 & 0,65 \\
2016. & 405 & 453413 & 772090 & 0,89 & 0,52 \\
$\Sigma$ & 1336 & 1579293 & 2293308 & 0,84 & 0,58 \\
\hline
\end{tabular}

The methods which are used for coal mining in Serbia's mines are at a very low technological level with a large part of manual work. This is also shown by this analysis (Tables 12 and 13) where a large number of injuries can be noticed in relation to the amount of coal excavated. The introduction of mechanization in the development of the mine and preparation drifts and for coal excavation, as well as the additional training of workers would lead to a reduction in the number of injured workers.

\section{CONCLUSION}

On the basis of the conducted research it follows that injuries at work are a constant companion of exploitation work in underground mines in Serbia, and that their cause is related to natural and technological solutions for the works on coal excavation. The frequency of injuries is expressed and a special problem is the high level of serious injury, which results in a longer sick leave and a certain degree of disability.

As the injuries have multiple negative impacts, it is imperative that mandatory safety measures are applied and consistently control their application in order to reduce the number of injuries. In addition, it is inevitable to modernize the technological phases of the underground exploitation process by strengthening the introduction of mechanized equipment, devices and plants in order to reduce the contribution of hard physical work and lead to a secure and safer work. The fact arising from the analysis is that injuries are caused mainly by carelessness and insecurity, which again indicates a low level of 
technological discipline and training of workers. The high frequency of injuries caused by excavation activities requires the modification and changing of existing excavation methods, ie the reduction of the share of manual work on excavation, the development works and the delivery of materials. This can be effectively solved by the introduction of continuous miners or by introducing longwall excavation in parts of the deposit, where natural - geological conditions allow it.

\section{REFERENCES}

IVKOVIĆ,M. (2010) Istraživanje parametara povređivanja radnika u RMU“Soko“ Sokobanja i sistematizacija mera za povećanje sigurnosti. In: Zbornik radova III međunarodnog simpozijuma „Energetsko rudarstvo, nove tehnologije, održivi razvoj. Univesity of Belgrade - Faculty of Mining and Geology, Beograd, pp.377-381.

IVKOVIĆ, M. (2012) Analiza povređivanja zaposlenih u podzemnim rudnicima uglja u Srbiji za period 2000-2010 godine. In: Usavršavanje tehnološkog procesa eksploatacije, unapređenje zaštite životne sredine $i$ poboljšanje bezbednosti $i$ zdravlja zaposlenih $u$ podzemnim rudnicima uglja $u$ Srbiji. Resavica: Komitet za podzemnu eksploataciju mineralnih sirovina, pp.122-130.

JP PEU (2016) Godišnji izveštaji o bezbednosti i zgravlju na radu JP PEU. Resavica: Tehnička uprava.

STOJADINOVIĆ, S. et al. (2012) Mining injuries in Serbian underground coal mines - A 10-year study. International Journal of the Care of the Injured, 43.

ĆURČIĆ, A. et al. (1981) Rezultati istraživanjauslova rada i posledica na zdravstveno stanje i radnu sposobnost radnika u rudnicima uglja sa podzemnom eksploatacijom sa ciljem utvrđivanja dužine trajanja radnog veka radnika. In: Zbornik radova $V$ jugoslovenskog simpozijuma „Preventivna zaštita u rudarstvu i metalurgiji“. Zenica; Savez inženjera i tehničara rudarske, geološke i metalurške struke Jugoslavije, pp. 263-278. 